\title{
Persatuan dan kesatuan sila ke 3 (Persatuan Indonesia)
}

\author{
Achmad Hasfa Jauhari \\ Prodi kesehatan masyarakat
}

lik strada indonesia

Kresekjr276@gmail.com

\begin{abstract}
Abstrak
Di tengah tantangan disintegrasi yang melibatkan bangsa Indonesia, sebagai bangsa yang majemuk, perlu bantuan untuk terus dapat peduli terhadap keragaman dengan menanamkan kesadaran multikulturalisme. Perbedaan budaya antara masing-masing budaya yang memiliki berbagai ciri khas yang unik tidak akan menyebabkan terbelahnya kesatuan, tetapi justru mempererat harmoni sosial karena antara keduanya dapat memberikan kebutuhan yang saling menguntungkan. Artikel ini membahas tentang menganalisis upaya-upaya untuk merawat Bangsa Indonesia sebagai bangsa yang multikultural agar senantiasa dapat membentuk persatuan dan kesatuan dalam kebhinekaan dengan mengedepankan semangat multikulturalisme, kebhinekaan, dan nilai-nilai instrumen Pancasila sebagai jalan untuk mengetahui kehidupan. dari bangsa dan negara.

Kata kunci: bangsa Indonesia sebagai bangsa yang majemuk, perlu bantuan terus dapat peduli terhadap keragaman.

\section{A. Latar belakang}

Pancasila lahir tanggal 1 Juni 1945. Pada saat itu, tokoh kemerdekaan Indonesia yang juga Presiden pertama Indonesia, Ir. Soekarno, mengusulkan rumusan pancasila dalam sidang pertama BPUPKI atau Badan Penyelidik Usaha-usaha Persiapan Kemerdekaan Indonesia. Bung Karno, panggilan Soekarno memberikan 5 gagasan yang kemudian disebut dengan Pancasila atau 5 sila.
\end{abstract}




\section{Ketuhanan yang meha Esa}

2.Kemanusiaan yang adil dan beradab

3.Persatuan Indonesia

4.Kerakyatan yang di pimpin oleh hikmat kebijaksanaan dalam permusyawaratan perwakilan

5. Keadilan sosial bagi seluruh rakyat Indonesia

Bunyi sila ke-3 adalah "Persatuan Indonesia". Menurut Badan Pembinaan Ideologi Pancasila, sila tersebut mengandung nilai sebagai landasan untuk menjaga persatuan dan kesatuan bangsa Indonesia. Dalam sila ke-3 tersebut, terdapat tujuh butir pengamalan, sebagai berikut:

1. Mampu menempatkan persatuan, kesatuan, serta kepentingan bangsa dan negara sebagai kepentingan bersama diatas kepentingan pribadi atau golongan.

2. Sanggup dan rela berkorban untuk kepentingan negara dan bangsa, apabila diperlukan.

3. Mengembangkan rasa cinta kepada tanah air dan bangsa.

4. Mengembangkan rasa kebanggaan berkebangsaan bertanah air Indonesia.

5. Melihara ketertiban dunia yang berdasarkan perdamaian abadi dan keadian sosial.

6. Mengembangka persatuan Indonesia atas dasar Bhineka Tunggal Ika.

7. Memajukan pergaulan Demi persatuan dan kesatuan bangsa. 


\section{B. Kasus masalah}

perang antar suku, tawuran antar pelajar, banyaknya aliran sesat yang muncul dan sebagainya. Salah satu kasus yang menyimpang sila ke tiga adalah Organisasi Papua Merdeka (OPM). Sebaiknya begini tidak harus dilakukan atau dilaksanakan agar negara kita bisa menjadi persatuan Indonesia bisa untuk dibanggakan. Tetapi kita harus menjaga negara kita agar tidak melakukan hal" yang arogan yang melanggar aturan dinegara Indonesia.

\section{Tinjauan Pustaka}

Hal yang ingin saya bahas pada teks ini adalah pada sila ke tiga. Dengan perkembangan teknologi yang berkembang pesat maka gaya hidup masyarakat pun secara perlahan ikut berubah. Hal ini pun membuat budaya secara tidak langsung mulai berubah karena masuknya budaya asing seiring berkembangnya teknologi. Karena adanya banyak budaya dan paham asing yang masuk bermunculanlah banyak komunitas komunitas yang menyebabkan adanya perpecahan di kalangan masyarakat yang melanggar sila ke tiga.

Oleh karena itu kita perlu Tindakan untuk meminimalisir atau mencegah banyak perselisihan antar masyarakat yang membuat persatuan Indonesia perlahan mulai runtuh. Ada beberapa cara yang mungkin dapat di manfaatkan untuk mencehal hal itu yakni:

1. program bela negara

Program ini bisa terbilang efektif bila di rencanakan matang matang. Jika tidak seperti itu maka akan menjadi sebuah event yang hanya di anggap sebagai acara saja tidak meninggalkan kesan kesan untuk meningkatkan jiwa kebangsaan pada masyarakat programini mungkin bisa efektif untuk di laksanakan untuk para pelajar siswa karena umur pelajar itu sangat dengan cepat belajar dan memahami materi yang di terimanya oleh karena itu program ini dapat efektif untuk pelajar di Indonesia.

\section{Kerja Bakti}

Cara ini memang sudah ada sejak dulu dan masih bertahan sampai sekarang. Namun, car aini mulai tidak terlihat khususnya di daerah kota. Hal itu bisa terjadi mungkin karena beberapa faktor seperti kesibukan kerja, tetangga tidak saling sapa menyapa, sudah ada petugas kebersihan sehingga tidak perlu adanya kerja bakti biasanya di daerah perumahan elite. Oleh karena itu perlu kita bangkitkan 
Kembali program kerja bakti ini untuk mempererat kebersamaan antar tetangga atau perumahan di sekitar kita.

\section{Di ajarkan hal hal positif}

Maksudnya di tanamkan prinsip prinsip yang bersifat positif kepada anak atau pelajar seperti kita harus menghargai orang yang lebih tua, mengingat jasa pahlawan, berbuat baik kepada sesama, serta memahami nilai nilai Pancasila yang mana memang di bentuk untuk menjadi sebuah pedoman hidup masyarakat di Indonesia.

\section{Memanfaatkan Media sosial}

Memanfaatkan media sosial untuk memberi wawasan dan informasi kepada masyarakat agar tidak memakan informasi palsu/HOAX yang banyak beredar di media sosial serta opini opini yang mengarah ke perselisihan antar komunitas atau kelompok yang berdampak buruk hingga bisa terjadi tawuran bahkan pembunuhan karena isu atau opini yang belum jelas kebenarannya contoh seperti yang biasa viral di kalangan milenial sekarang adalah Drama antar public figure yang sebenarnnya hanya bercanda namun ada pihak lain yang membuat seolah olah itu memang benar terjadi hal itu menyebabkan keuntungan satu pihak dan merugikan yang lain. Ini lah yang sebenarnya harus di cegah di kalangan milenial jaman sekarang.

5. meningkatkan pelajaran kewarganegaraan disekolah

Kita mungkin sudah tau pelajaran yang sudah ada pada saat sd namun menurut saya kurang efektif untuk sekarang ini. Karena pada saat pembelajarannya hanya di ajarkan secara teori, mungkin jika di tambahkan secara praktek mungkin bisa lebih efektif karena menurut saya pada saat mengajar kepada anak khususnya seusia sd, pembelajaran praktek mungkin bisa sangat efektif karena bila anak bisa langsung mempraktekan secara langsung maka mereka bisa langsung mengingat dan memahami materi yang di bagikan oleh gurunya dan akan di praktekan di kehidupan sehari harinya. Contoh simplenya mungkin jika ketemu guru di jalan disapa dengan sopan atau lebih bagus sambil cium tangan.

Dengan cara di atas kemungkinan dapat di gunakan untuk pemerintah atau sekolah agar dapat menanamkan jiwa Pancasila pada kalangan remaja remaja di Indonesia karena pihak yang sangat efektif untuk mengubah budaya atau gaya hidup adalah dengan cara di tanamkan pada kalangan pelajar atau anak anak usia dini.

D. Kesimpulan 
Untuk sila ke 3 dengan berkembangnya teknologi yang begitu pesat maka gaya hidup masyarakat pun secara perlahan ikut berubah. Hal ini pun membuat budaya secara tidak langsung mulai berubah karena masuknya budaya asing melalui berkembangnya teknologi. Bermunculnya komunitas komunitas yang menyebabkan adanya perpecahan dikalangan masyarakat yang melanggar sila ke tiga.

Oleh karena itu kita perlu ada tindakan meminimalisir atau mencegah banyak perselisihan antar masyarakat yang membuat persatuan Indonesia mulai runtuh. Beberapa cara mungkin untuk dimanfaatkan untuk mencegah hal itu terjadi yaitu: progam bela negara, kerja bakti, diajarkan hal hal positif, memanfaatkan media sosial dan meningkatkan pelajaran kewarganegaraan disekolah.

Daftar pustaka

Attoriq, S., \& Sodik, MA (2018). Pencegahan Dan Pengendalian Infeksi Terkait Pelayanan Kesehatan Di Lahan Praktik. 